\title{
Erratum to "Anesthetic Dilemma: Spinal Anesthesia in a Severe Pre-Eclamptic Patient with Twin Gestation, Heart Failure and Acute Pulmonary Edema"
}

\author{
E. O. Oyebamiji ${ }^{*}$, B. B. Osinaike ${ }^{1}$, B. T. Olaifa ${ }^{1}$, A. A. Adeniji ${ }^{2}$ \\ ${ }^{1}$ Department of Anesthesia, Ladoke Akintola University of Technology Teaching Hospital, Osogbo, Nigeria \\ ${ }^{2}$ Department of Obstetrics \& Gynecology, Ladoke Akintola University of Technology Teaching Hospital, Osogbo, \\ Nigeria \\ Email: "droyebamiji@gmail.com
}

Received 10 February 2015; accepted 10 April 2015; published 13 April 2015

Copyright (C) 2015 by authors and Scientific Research Publishing Inc.

This work is licensed under the Creative Commons Attribution International License (CC BY).

http://creativecommons.org/licenses/by/4.0/

(c) (i) Open Access

The original online version of this article (Oyebamiji, E.O., Osinaike, B.B., Olaifa, B.T. and Adeniji, A.A. (2015) Anesthetic Dilemma: Spinal Anesthesia in a Severe Pre-Eclamptic Patient with Twin Gestation, Heart Failure and Acute Pulmonary Edema, 2015, 5, 208-212.

http://dx.doi.org/10.4236/ojog.2015.54030) was published in April, 2015 with one incorrect affiliation. We revised the authors' affiliations of the article. The authors wish to correct the errors to:

\section{E. O. Oyebamiji ${ }^{*}$, B. B. Osinaike ${ }^{2}$, B. T. Olaifa ${ }^{1}$, A. A. Adeniji ${ }^{3}$}

\footnotetext{
${ }^{1}$ Department of Anesthesia, Ladoke Akintola University of Technology Teaching Hospital, Osogbo, Nigeria

${ }^{2}$ Department of Anesthesia, University of Ibadan/University College Hospital, Ibadan, Nigeria

${ }^{3}$ Department of Obstetrics \& Gynecology, Ladoke Akintola University of Technology Teaching Hospital, Osogbo, Nigeria

Email: "droyebamiji@gmail.com
} 